\title{
The natural recovery of disturbed soil, plant cover and trees after clear-cutting in the boreal forests, Russia
}

\author{
Aleksey llintsev ${ }^{(1-2)}$, \\ Alexander Bogdanov ${ }^{(1-2)}$, \\ Elena Nakvasina ${ }^{(2)}$, \\ Irina Amosova ${ }^{(3)}$, \\ Sergey Koptev ${ }^{(2)}$, \\ Sergey Tretyakov ${ }^{(2)}$
}

\begin{abstract}
This study aims to determine the impact of forest harvesting machinery on the temporarily moist soil of spruce forests (Picea abies Karst.) during the summer. For research purposes, we investigated 23 sites of the boreal forest in the European North of Russia (Arkhangelsk region) where logging operations had been carried out using harvesters and forwarders (CTL, cut-to-length harvesting). In the 15 years after logging, the sites were monitored for changes in physical soil properties and the depth/width of ruts and vegetation. In freshly cut areas, the depth of the ruts was linked to the amount of logging residue that had been used to strengthen skidding trails. After 15 years, the ruts were smooth but had not disappeared entirely. The average depth of the ruts decreased from $36 \mathrm{~cm}$ to $18 \mathrm{~cm}$ during the period under review. At a depth of 0$10 \mathrm{~cm}$, the soil bulk density of the section between the control area and the wheel track increased by $19-27 \%$ within the first two years. At a depth of $10-$ $20 \mathrm{~cm}$, the soil bulk density only increased by $16-17 \%$ within the two-year period. After 15 years, the soil bulk density had decreased to the extent that there were no signs of heavy machinery movement. The natural restoration of vegetation in the ruts was affected by the presence of stagnant water in the initial post-logging period. Ruderal species and species with broad ecological amplitude to environmental factors grew over the skid trails. 15 years after logging, this overgrowth had stabilised, with the biodiversity level in the control area approaching its pre-logging state. Primarily, the renewal of the cutting areas occurred through species such as birch (Betula pendula Roth.) and aspen (Populus tremula L.). The highest amount of undergrowth (more than $30,000 \mathrm{ha}^{-1}$ ) was detected 6-8 years after logging. This then decreases in areas that were cut down earlier. There are environmental consequences of clearcutting (using the CTL system) on temporarily moist soil. To prevent the formation of deep ruts, it is recommended to leave $15-20 \mathrm{~kg} \mathrm{~m}^{-2}$ of felling residue.
\end{abstract}

Keywords: Clear-cuttings, Soil Disturbance, Rutting, Vascular Species, Natural Tree Regeneration

\section{Introduction}

Forest management has become a controversial topic as a result of fundamental differences in how forest resources are viewed. The recreational value and biodiversity of forest ecosystems and oldgrowth forests are increasingly being recognised. There is also an increasing demand for wood, as it is an environmentally friendly product (Gustafson 1996).

In Russia, the amount of clear-cutting areas has been increasing, already reaching over one-million hectares in size. Timber harvesting in the European North of Russia remains at a high level, as the area contains significant wood stocks. Under current conditions, about 14 million $\mathrm{m}^{3}$ of wood has been cut down by private corporations in
(1) Northern Research Institute of Forestry, Arkhangelsk 163062 (Russia); (2) Department of Silviculture and Forest Management, Northern (Arctic) Federal University named after M.V. Lomonosov, Arkhangelsk 163002 (Russia); (3) Department of Biology, Ecology and Biotechnology, Northern (Arctic) Federal University named after M.V. Lomonosov, Arkhangelsk 163002 (Russia)

\section{@ Aleksey Ilintsev (a.ilintsev@narfu.ru)}

Received: Feb 10, 2020 - Accepted: Sep 14, 2020

Citation: Ilintsev A, Bogdanov A, Nakvasina E, Amosova I, Koptev S, Tretyakov S (2020). The natural recovery of disturbed soil, plant cover and trees after clear-cutting in the boreal forests, Russia. iForest 13: 531-540. - doi: 10.3832/ifor3371-013 [online 2020-11-18] the Arkhangelsk region. This is approximately half of the estimated permitted cutting. The Arkhangelsk region is one of the five biggest wood harvesting areas in Russia (Anonymous 2018).

Overall, $18.1 \%$ of operational forests in the region grow on soil with excessive moisture (sphagnosa and uliginoso-herbosa forests), whilst $26.9 \%$ grow on soil with temporarily excessive moisture (polytrichosa and myrtillosum forests). This affects productivity and transport accessibility. Due to a lack of year-round roads, most forest stands can not be harvested during the summer. In light of this, over $66 \%$ of harvested wood is felled and transported during the wintertime.

Climate change has affected seasonal weather patterns (IPCC 2013). According to local weather stations, over the last decade, the average temperature has increased by $0.8-1.3{ }^{\circ} \mathrm{C}$ (Anonymous 2018). Precipitation has also been increasing throughout Russia, though such figures ing is more pronounced in Northern regions than in the South. According to rehave remained within normal limits. Warm- 
cent forecasts, European Russia is expected to undergo an increase in average air temperature and average annual rainfall. This will lead to an increase in cold periods, a change in dynamics and higher frequency of extreme weather phenomena (e.g., severe frosts, heavy precipitation, strong winds and river flooding).

When logging on soil with excessive or temporarily excessive moisture, driving on frozen soil is crucial. Logging on frozen soil covered by snow is more effective, as it causes less damage to the soil surface (Modry \& Hubeny 2003, Susnjar et al. 2006, llintsev et al. 2018). However, climate change has reduced the duration of the soil-freezing period, shifting the timing of both its onset and its end (Toivioa et al. 2017, Sirén et al. 2019). This impacts the timing of logging operations.

Logging sites with temporarily or excessively moist soil are particularly environmentally vulnerable. Due to its excessive moisture, this soil is characterised by low bearing capacity, poor drainage and disturbed water-air regimes. It is necessary to consider the impact of logging equipment on the restoration of post-harvest soil, ground cover and woody vegetation. Each of these elements plays a significant part in the structural organisation and functional abilities of forest ecosystems (Cambi et al. 2015, Smirnova et al. 2017, Dymov 2017). In order to prevent potentially damaging post-harvest environmental processes, logging operations on soil with excessive or temporarily excessive moisture must undertake specific measures.

The environmental impact of logging is of significant scientific interest. The primary issues are associated with the introduction of new equipment and technologies. Since
1980 , interest in green logging has been increasing, due to the implementation of new felling and bunching equipment (e.g., the Timberjack 850). This equipment is considered to have a significantly negative impact on soil and the natural regeneration of coniferous species (Pobedinskii 2013). The implementation of new logging machines (harvesters and forwarders) does not always ensure that the forest is preserved (Eliasson 2005, Terinov et al. 2016).

Currently, logging operations in the Arkhangelsk region are mainly carried out using two systems: Scandinavian cut-tolength (CTL) harvesting, which uses a harvester and a forwarder, and Canadian treelength ( $T L$ ) harvesting, which uses a fellerbuncher and a tracked skidder. In Russia, CTL harvesting is increasingly being used instead of TL harvesting, as it is more efficient (Goltsev et al. 2011). In Finland and Sweden, almost all logging is done using harvesters and forwarders (Eliasson 2005). Previous studies suggest that a large time scale is crucial in the analysis of the soil and forest cover restoration process (Modry \& Hubeny 2003, Marchi et al. 2016, Dymov 2017, Mohieddinnea et al. 2019). The longterm characteristics of the recovery process are evident several decades after logging. In some cases, irreversible damage occurs (Hartmann et al. 2014, Klaes et al. 2016). The effects of selective and smallscale, narrow cuts are much weaker than those of clear-cutting (Pobedinskii 2013, IIintsev et al. 2018, 2019a). Large areas of clear-cutting and harsh climatic conditions often hamper the natural regeneration process (Melehov 2003). Although the average area of clear-cutting is approximately 25-30 hectares, there are several acute issues linked to the natural renewing of felling areas, especially in cutting areas with temporarily excessive or excessive moisture. This is due to the post-cutting species changes that are typical of these regions.

Further scientific research in this area is crucial, due to the active growth of logging, the complexity of logging operations that use modern forest machinery and the environmental impact of logging on forests. These factors affect the effectiveness of subsequent natural tree regeneration and the development of future forest communities.

It is impossible to completely mitigate the impact of modern logging technologies on the forest environment. However, the negative environmental consequences of logging should be minimised at local, regional and global levels (Marchi et al. 2018). Practical and technological solutions should be proposed to limit and/or minimise the negative effects of logging equipment on soil.

This study aims to examine the impact patterns of using forest machinery on temporarily moist soil during the summer and assess the emerging conditions of the development of vegetation cover in the recovery dynamics.

To achieve this, the following tasks were undertaken: (i) the evaluation of the parameters of soil rutting on machine operating trails and the analysis of its relationship with the amount of cutting residue; (ii) the determination of the compaction of upper soil horizons in cutting areas from various years; (iii) the tracking of plant species recovery, which is dependent on the time since logging; (iv) the characterisation of the natural tree regeneration of cutting areas in each year after logging.

It has been assumed that, in the case of

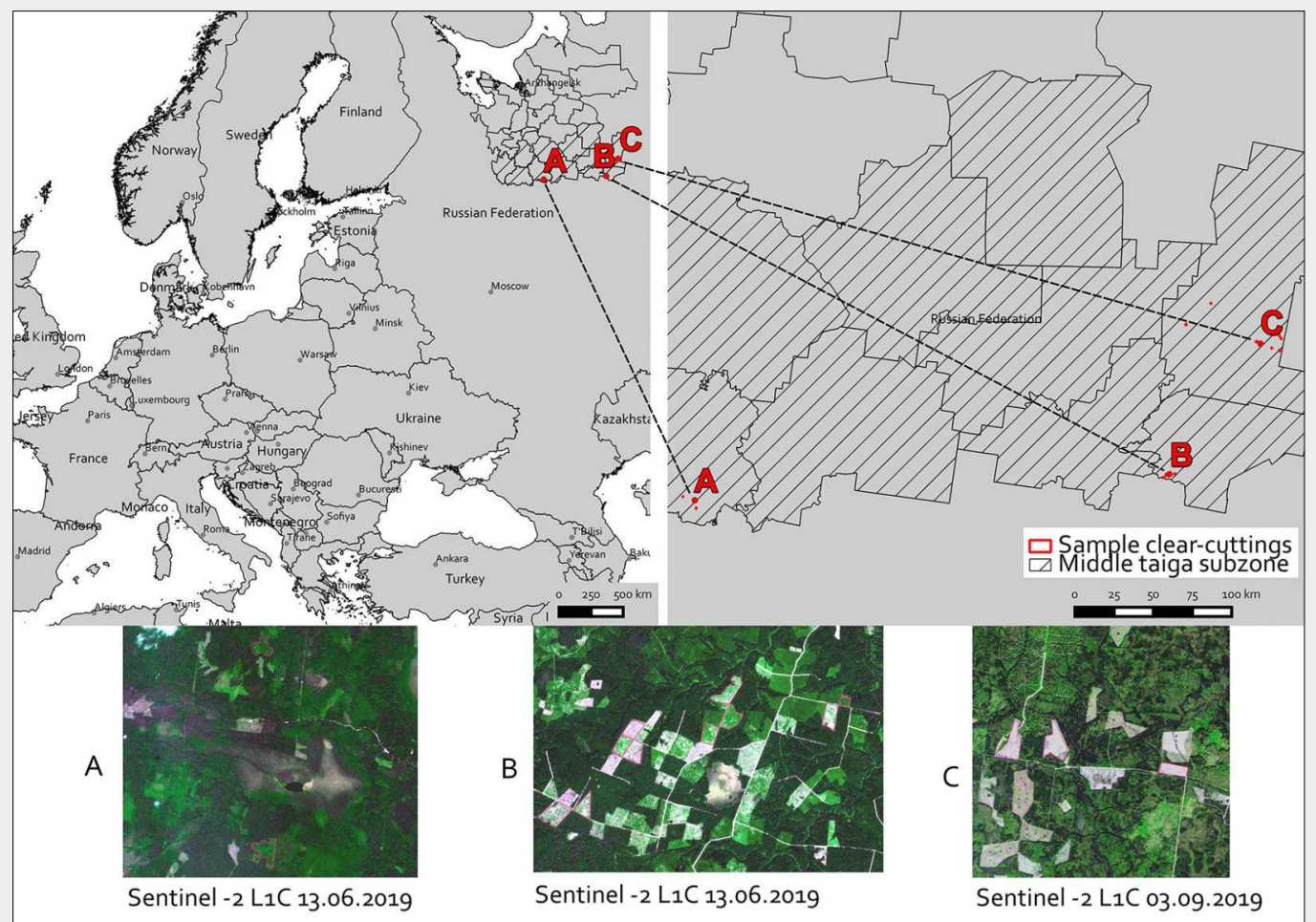

Fig. 1 - Location of study area and experimental clear-cuttings. 


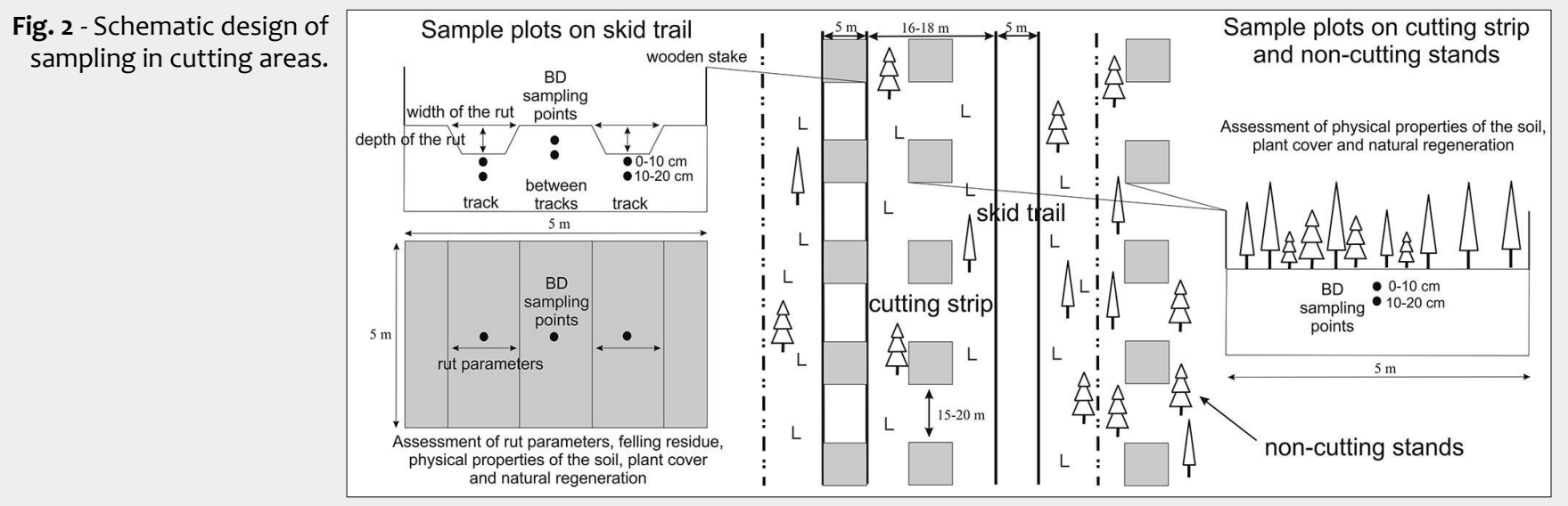

clear-cuttings in forest stands with temporarily moist soils, logging machinery leads to the compaction of upper soil horizons and the disturbance of the soil cover. This is due to the occurrence of ruts, which persist for a long time during the natural regeneration process.

\section{Materials and methods}

\section{Study site and forest growing conditions}

The study was carried out in Arkhangelsk, a multi-forest region in the European North of Russia (Fig. 1). The research areas were located in three administrative districts of the Arkhangelsk region. According to forest zoning, the research area is part of the middle taiga subzone (Kurnaev 1973).

The climate in the study area is moderately continental, with a long, cold and snowy winter, a short and variable spring, a relatively short and moderately warm summer and a long, rainy autumn. The annual radiation balance is $35 \mathrm{kcal} \mathrm{cm}^{-2}$. Due to the high transparency of the atmosphere, temperatures fall to under $-40{ }^{\circ} \mathrm{C}$ in the winter and exceed $30^{\circ} \mathrm{C}$ in the summer. The duration of the growing season is determined by the number of days with temperature $>5{ }^{\circ} \mathrm{C}$. During the study period, this was 150-160 days. The period of active vegetation (the number of days with a temperature above $10{ }^{\circ} \mathrm{C}$ ) is approximately 100-110 days. In late May and early June, there is a high probability of frost. The average annual precipitation is approximately $700 \mathrm{~mm}$.

The main adverse climatic factors for the growth and development of tree species include excessive moisture during the growing season and insufficient heat during the late spring and summer.

Norway spruce (Picea abies Karst.) and Scots pine (Pinus sylvestris L.) forests cover $66.4 \%$ of the research area. As a result of the wide range of soils, spruce (myrtillosum, myrtillosum-wet and polytrichosa) forms stands of various types and productivity levels. Myrtillosum spruce stands tend to grow on flat terrain with typical, podzolic soil (Haplic Albeluvisols). Wet myrtillosum and polytrichosa spruce stands are formed in slightly drained areas with loamy and binomial parent soil. They form on Gleyic and Histy-Gleyic Albeluvisols, as well as Gleyic Podzols (Soil Data Center 2011, IUSS Working Group 2015). Forest stands of medium and low (class IV and V) productivity tend to dominate in the study area. The granulometric composition of the soil is mainly loamy sands and sandy loams. In these conditions, signs of gleying are caused by surface over-wetting due to soft water precipitation. This precipitation is largely retained by powerful moss covers of Polytrichum commune (Soil Data Center 2011).

\section{Stands and forest logging}

To assess the physical properties of the soil, soil rutting to the soil surface, plant cover and natural tree regeneration, 23 felling sites (all appropriate for the experiment conditions) were selected. The clearcuts were not planted with seedlings after logging but left for natural regeneration. The sites had different logging periods and each had non-logged stands with similar forest growing conditions. The original plots mainly comprised mixed stands of Norway spruce, Scots pine, birch (Betula pendula Roth.) and aspen (Populus tremula L.). The stock of the mature and over mature stands ranged from $89 \mathrm{~m}^{3}$ ha $^{-1}$ to 329 $\mathrm{m}^{3} \mathrm{ha}^{-1}$. The classes of productivity ranged from medium to low (III to V). Myrtillosumwet forest was the most common forest type (see Tab. S1 in Supplementary material).

On all the sites, logging operations had been carried out using harvesters and forwarders (CTL harvesting). The cutting areas were developed during the summer. The felling of trees, the pruning of branches, bucking and the shredding of felling residue was carried out by a John Deere $1270^{\circ}$ (Moline, IL, USA), a six-wheel harvester with a weight of $20,650 \mathrm{~kg}$, engine power of $190 \mathrm{~kW}$ and specific ground pressure of $69 \mathrm{kPa}$. The cutting areas were developed using narrow cutting strip technology, whereby the width of skid trails did not exceed $5 \mathrm{~m}$ and the width of cutting strips was $16-18 \mathrm{~m}$.

The gathering and transportation of logs were carried out by a John Deere $1210^{\circledR}$, an eight-wheel forwarder with a weight of $18,080 \mathrm{~kg}$, load capacity of $13,000 \mathrm{~kg}$, engine power of $156 \mathrm{~kW}$ and specific ground pressure of $50 \mathrm{kPa}$. According to the harvest site planning map, the total area of the skid trails cut during the logging process did not exceed $30 \%$ of the cutting area. The skidding distance ranged from 200-700 $\mathrm{m}$. The total area of log loading points and household facilities was dependent on the total cutting area. Loading points were set up along logging roads.

The intensity of logging was $95 \%$ of the original growing stock. To ensure natural regeneration, during the cutting area development, 20 pine/spruce seed trees were left per hectare. Non-operational forest areas that contained natural values of environmental significance were preserved. To ensure biological diversity, single trees of all species present in the stand and the second floor of spruce trees were also preserved.

In all the sites, the clearing of cutting areas was carried out alongside the felling of forest stands and the skidding of wood. This was done by laying felling residues on skid trails, as this strengthened them and protected the soil from strong compaction/ damage during skidding.

\section{Data collection and analysis}

\section{Experimental design and data collection}

For the fieldwork, sample plots $(5 \times 5 \mathrm{~m}$ in size) were positioned in the skid trails, cutting strips and forest stands where logging had not been carried out, the latter acting as control areas. A series of sample plots were laid 15-20 m apart (Fig. 2). At each clear-cut, 15 sample plots were located in the skid trails and cutting strips. Therefore, in the 23 clear-cuts, the number of sample plots was 690 . In the three non-cutting stands, there were 45 sample plots. The total number of sample plots was 735 .

The rut parameters were measured in the sample plots located on skid trails. The width and depth of the left and right ruts were measured in the middle of their length within the sample plot. The average depth and width of the rut were measured 
to the left and right of the wheel tracks. The ruts' parameters were measured using two measuring metal tapes. One was stretched to measure the rut width and the other was stretched to measure the depth of the centre of the rut. 30 width/depth measurements were taken in each cutting area. The total number of measurements taken in all the clear-cuts was 690 .

In the places where the parameters of the rut were evaluated, the number of felling residues in the skid trails was also determined.

Soil samples were only collected in six cutting areas (1, 2, 6, 9 and 15 years after logging) and three non-cutting stands adjacent to these clear-cuts. Soil samples were taken using a cylindrical metal sampler with a volume of $52.78 \mathrm{~cm}^{3}$, diameter of 4.1 $\mathrm{cm}$ and length of $4 \mathrm{~cm}$. Each sample plot was located in the skid trails. Two soil samples were taken to the left and the right of the tracks (in their central part within the sample area), as well as in between of the tracks (at a depth of $0-10 \mathrm{~cm}$ and $10-20 \mathrm{~cm}$ ). At each of the sample plots located in cutting strips, 2 soil samples were taken at the same depth. Sixty soil samples were taken in the tracks, 30 in between the tracks and 30 in cutting strips, thus 120 soil samples were taken per cutting area. For the six cutting stands, the total number of soil samples was 720 . In the three non-cutting stands, 2-4 samples were taken in the sample plots. The total number of soil samples collected from non-cutting stands was 120 . The overall number of soil samples was 840.

The plant cover and extent of natural tree regeneration were evaluated for all sample plots. However, for sample plots located in the skid trails, they were evaluated both within and outside the tracks. There were 690 sample plots within the skid trails and 345 in the cutting strips, as well as 45 sample plots in the three non-cutting stands, totaling an overall number of 1080 sample plots.

\section{Amount of logging residue on skid trails}

The amount of felling residue was estimated by using the weight method in the sample plots ( $1 \times 1 \mathrm{~m}$ in size). At the sample plots, felling residues were collected and weighed on a scale that was accurate to 1 $\mathrm{kg}$. Seventy measurements were made for the five fresh clear-cuts. The weight of the large waste (over $15 \mathrm{~kg}$ ) was determined using the diameter, length and conversion coefficient for the wood species.

For large pieces of logging residuals, the volume was calculated as follows (eqn. 1):

$$
V=3.14 \cdot d_{m}^{2} \cdot \frac{L}{4} \cdot 10.000
$$

where $d_{\mathrm{m}}$ is the median diameter $(\mathrm{cm})$ and $L$ is the length $(m)$ of the log.

The median diameter of the log was measured using a classic diameter calliper and the length was measured using metal tape.

To convert the volume into a weight, co- efficients of wood species were used, which are given in regulatory documents. For example, $1 \mathrm{~m}^{3}$ of semi-dry pinewood weighs $600 \mathrm{~kg}$, whilst the same volume weighs 550,710 , and $350 \mathrm{~kg}$ for spruce, birch and aspen, respectively.

\section{Physical properties of soil}

All the soil samples were weighed on analytical scales that were accurate up to 0.01 g. Then, the samples of constant mass were dried in an oven at $105{ }^{\circ} \mathrm{C}$. The physical properties of the soil were then determined using eqn. 2 , eqn. 3 and eqn. 4 .

The bulk density was calculated using eqn. 2 (Osman 2013):

$$
D_{b}=\frac{W_{D}}{V}
$$

where $D_{\mathrm{b}}$ is the bulk density $\left(\mathrm{g} \mathrm{cm}^{-3}\right), W_{D}$ is the mass of completely dry soil ( $g$ ) and $V$ is the volume $\left(\mathrm{cm}^{3}\right)$. Particle density was obtained using the pycnometric method (Pall \& Mohsenin 1980).

The composition density and density of the solid phase of the soil were used to calculate the total porosity, which was determined by eqn. 3 (Osman 2013):

$$
\varphi=\left(1-\frac{D_{b}}{D_{d}}\right) \cdot 100
$$

where $\varphi$ is the total porosity (\%) and $D_{d}$ is the particle density $\left(\mathrm{g} \mathrm{cm}^{-3}\right)$.

The aeration porosity (the proportion of large pores occupied by air) was calculated using eqn. 4 (Osman 2013):

$$
\varphi_{a}=\varphi-M \cdot D_{b}
$$

where $M$ is the moisture content (\%) and $\varphi_{\mathrm{a}}$ is the aeration porosity (\%).

\section{Plant cover}

The total projection coverage of moss and grass-shrub layers and individual species was determined as a percentage, allowing for the estimation of plant cover renewal. The identification of the detected plant species was performed using standard determinants (Plantarium 2020). Nomenclature followed the current international database of plants (WFO 2020).

To compare the plant cover across the studied areas, the plant species similarity (Jaccard's index) was calculated using eqn. 5 (Krebs 1999):

$$
I_{j}=\frac{c}{a+b-c}
$$

where $c$ is the percentage of common species in the two communities, $a$ is the percentage of species only found in the first community and $b$ is the percentage of species only found in the second community. If $I_{j}<50 \%$, the similarity is low. If $I_{j}>$ $50 \%$, the similarity is high.

To aid the analysis of plant cover, vascular plants were categorised based on bio-morphological (e.g., shrubs and grasses) or ecological-cenotic (e.g., forests, meadows, wetlands and weed-ruderals) attributes. The bio-morphological plants were then divided into graminoid and motley grass (Nitsenko 1969a, 1969b).

\section{Natural tree regeneration}

All woody plants with a diameter at breast height $(\mathrm{DBH})<6 \mathrm{~cm}$ were recorded. A classic diameter calliper was used to measure the DBH. The list was then classified according to tree species. Based on field data, the amount of undergrowth per hectare and its composition by species were determined.

\section{Statistical analysis}

Reasonable conclusions were made at a $5 \%$ probability level. Before the selection of a statistical analysis method, all the data was checked for distribution normality (using the Kolmogorov-Smirnov test) and uniformity of variances (using Levene's test). To examine the impact of time on rut parameters, the physical properties of the soil and natural tree regeneration, a oneway analysis of variance (ANOVA) was used. In the ANOVA of all the groups, posthoc Tukey's HSD test was used for multiple comparison of average values. To examine the strength of the relationship between the rut depth and the amount of logging residue, Pearson's correlation coefficient was calculated. Further, to describe the relationship between the rut depth and the amount of logging residue, regression analysis was used. Data processing and analysis were performed using Minitab $^{\circledast}$ ver. 17 (Minitab LLC, PA, USA) and Statistica ${ }^{\circledR}$ ver. 12.0 (StatSoft Inc., Tulsa, OK, USA).

\section{Results}

\section{Rutting and logging residues}

In the skid trails, a significant part of the soil was covered by felling residue. This protected the soil surface from the direct impact of logging equipment. However, in places where the amount of felling residue was insufficient or absent, rutting to the soil surface was observed. Analysis of the soil surface violations showed that these occurred relatively frequently, due to rut formations of differing widths and depths (Tab. 1).

The average width and depth of the rut varied according to the time since logging. In the first two years after logging, the average rut width was between 112 and 118 $\mathrm{cm}$. The minimum value was $90 \mathrm{~cm}$, whilst the maximum was $210 \mathrm{~cm}$. The maximum width of the ruts corresponded with the passages of the logging equipment. The average rut depth was $33-36 \mathrm{~cm}$. The minimum value was $5 \mathrm{~cm}$, whilst the maximum was $70 \mathrm{~cm}$. The maximum rut depth value seemed linked to the ground clearance of logging equipment.

As the time after cutting increased, the average depth and width of the ruts decreased. A single-factor analysis of variance confirmed the change in average rut depth 
and width over the period considered. After 15 years from logging, the average rut width was $40.6 \mathrm{~cm}$, the minimum was 15 $\mathrm{cm}$ and the maximum was $80 \mathrm{~cm}$. Meanwhile, the average depth of the rut was $14.9 \mathrm{~cm}$, the minimum was $2 \mathrm{~cm}$ and the maximum value was $35 \mathrm{~cm}$.

The logging residue was distributed unevenly over the soil surface (Fig. 3). The amount of felling residue in the cutting area ranged from 0 to $55 \mathrm{~kg} \mathrm{~m}^{-2}$. The average amount ( \pm standard deviation) of the felling residue was $12.00 \pm 11.04 \mathrm{~kg} \mathrm{~m}^{-2}$.

The relationship between the amount of logging residue and rut depth was notable (Fig. 3). It can be described using the exponential regression equation $\left(R^{2}=0.66-\right.$ eqn. 6).

$$
D=60.8911 \cdot \exp (-0.1028 \cdot L)
$$

where $D$ is the rut depth $(\mathrm{cm})$ and $L$ is the logging residue $\left(\mathrm{kg} \mathrm{m}^{-2}\right)$.

The greater the amount of felling residue, the fewer deep ruts in the skid trails were recorded. In this case, the impact of the number of forwarder passes was not considered. The correlation coefficient $(r=$ -0.81 ) between the studied features was statistically significant $(p<0.0001)$.

\section{Physical soil properties}

In the first nine years after logging, at a depth of $0-10 \mathrm{~cm}$, there was a significant difference (Tab. 2) between the soil bulk density of the area between the tracks and the untracked area. The bulk density between the tracks was $12.6-26.9 \%$ higher than that of the control area. Fifteen years after logging, the soil bulk density was still $10.9 \%$ higher between the tracks than in
Tab. 1 - Depth and width of the ruts on skid trails in different years after logging. (SD): standard deviation; (CV): coefficient of variation. Different letters after means indicate significant differences after Tukey's HSD test $(\alpha=0.05)$.

\begin{tabular}{ccccccc}
\hline $\begin{array}{c}\text { Years after } \\
\text { logging }\end{array}$ & \multicolumn{2}{l}{ Rut width $(\mathbf{c m})$} & \multicolumn{4}{l}{ Rut depth (cm) } \\
\cline { 2 - 7 } & Mean & \multicolumn{1}{c}{ SD } & CV (\%) & Mean & \multicolumn{1}{c}{ SD } & CV (\%) \\
\hline 1 & $112.6^{\mathrm{AB}}$ & 14.1 & 12.5 & $36.3^{\mathrm{A}}$ & 17.2 & 47.4 \\
\hline 2 & $117.7^{\mathrm{A}}$ & 12.5 & 10.6 & $33.2^{\mathrm{AB}}$ & 10.2 & 30.7 \\
\hline 3 & $108.6^{\mathrm{B}}$ & 16.8 & 15.5 & $29.4^{\mathrm{BC}}$ & 12.8 & 43.7 \\
\hline 4 & $90.0^{\mathrm{CD}}$ & 15.5 & 17.3 & $21.3^{\mathrm{CD}}$ & 6.5 & 30.6 \\
\hline 5 & $85.3^{\mathrm{D}}$ & 14.6 & 17.2 & $21.2^{\mathrm{D}}$ & 9.5 & 45.1 \\
\hline 6 & $83.0^{\mathrm{D}}$ & 11.7 & 14.1 & $21.3^{\mathrm{D}}$ & 10.2 & 47.9 \\
\hline 7 & $97.9^{\mathrm{C}}$ & 12.7 & 13.0 & $24.6^{\mathrm{BCD}}$ & 16.7 & 67.6 \\
\hline 9 & $80.3^{\mathrm{D}}$ & 20.1 & 25.0 & $24.5^{\mathrm{BCD}}$ & 9.0 & 36.8 \\
\hline 13 & $51.5^{\mathrm{E}}$ & 17.8 & 34.7 & $14.6^{\mathrm{D}}$ & 7.1 & 48.2 \\
\hline 15 & $43.4^{\mathrm{E}}$ & 15.9 & 36.6 & $17.8^{\mathrm{D}}$ & 9.9 & 63.0 \\
\hline F-value & 171.45 & - & - & 22.10 & - & - \\
\hline P-value & $<0.001$ & - & - & $<0.001$ & - & - \\
\hline
\end{tabular}

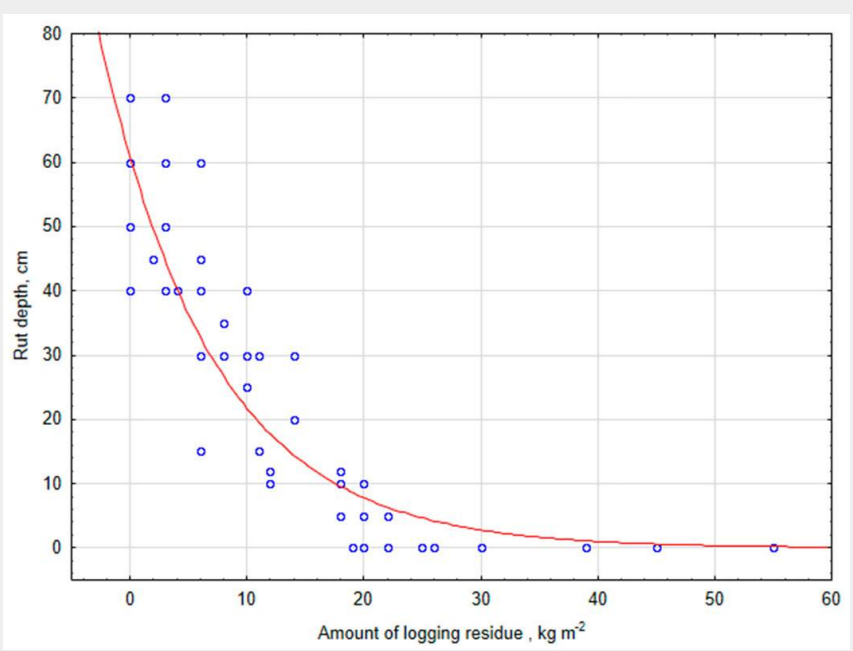

Fig. 3 - The relationship between the amount of logging residue and the rut depth.

Tab. 2 - Soil physical properties at a depth of 0-10 cm in different years after logging. (SD): standard deviation; (CV): coefficient of variation. Different letters after means indicate significant differences after Tukey's HSD test $(\alpha=0.05)$.

\begin{tabular}{|c|c|c|c|c|c|c|c|c|c|c|}
\hline \multirow{2}{*}{$\begin{array}{l}\text { Years after } \\
\text { logging }\end{array}$} & \multirow{2}{*}{ Sampling site } & \multicolumn{3}{|c|}{ Bulk density $\left(\mathrm{g} \mathrm{cm}^{-3}\right)$} & \multicolumn{3}{|c|}{ Total porosity (\%) } & \multicolumn{3}{|c|}{ Aeration porosity (\%) } \\
\hline & & Mean & SD & CV (\%) & Mean & SD & CV (\%) & Mean & SD & CV (\%) \\
\hline Untouched & Control & $1.19^{D}$ & 0.14 & 11.8 & $52.1^{\mathrm{A}}$ & 5.9 & 11.3 & $17.9^{\mathrm{AB}}$ & 7.7 & 43.1 \\
\hline \multirow[t]{3}{*}{1} & Tracks & $1.42^{A B}$ & 0.20 & 13.9 & $45.4^{\mathrm{CDE}}$ & 7.6 & 16.7 & $10.6^{D}$ & 4.1 & 39.3 \\
\hline & Between tracks & $1.26^{\mathrm{CD}}$ & 0.18 & 14.3 & $50.2^{\mathrm{ABC}}$ & 7.4 & 14.8 & $13.6^{\mathrm{BCD}}$ & 5.8 & 42.5 \\
\hline & Cutting strips & $1.19^{\mathrm{CD}}$ & 0.19 & 16.2 & $52.9^{\mathrm{A}}$ & 8.0 & 15.0 & $15.9^{B C}$ & 5.7 & 35.9 \\
\hline \multirow[t]{3}{*}{2} & Tracks & $1.51^{\mathrm{A}}$ & 0.26 & 16.9 & $40.6^{\mathrm{E}}$ & 10.1 & 24.7 & $10.7^{D}$ & 5.9 & 55.2 \\
\hline & Between tracks & $1.33^{\mathrm{ABCD}}$ & 0.15 & 10.9 & $47.8^{\mathrm{ABCDE}}$ & 5.7 & 11.9 & $13.6^{\mathrm{BCD}}$ & 6.2 & 45.7 \\
\hline & Cutting strips & $1.31^{\mathrm{BCD}}$ & 0.16 & 12.3 & $48.5^{\mathrm{ABCDE}}$ & 6.3 & 13.0 & $14.2^{\mathrm{BCD}}$ & 5.2 & 36.7 \\
\hline \multirow[t]{3}{*}{6} & Tracks & $1.47^{\mathrm{AB}}$ & 0.15 & 10.3 & $42.4^{\mathrm{DE}}$ & 5.9 & 14.0 & $11.8^{\mathrm{CD}}$ & 5.3 & 45.1 \\
\hline & Between tracks & $1.27^{\mathrm{BCD}}$ & 0.25 & 19.7 & $50.0^{\mathrm{ABCD}}$ & 9.8 & 19.7 & $12.6^{\mathrm{BCD}}$ & 6.3 & 50.2 \\
\hline & Cutting strips & $1.28^{\mathrm{BCD}}$ & 0.09 & 7.42 & $49.9^{\mathrm{ABCD}}$ & 3.7 & 7.4 & $15.1^{\mathrm{BCD}}$ & 5.3 & 35.0 \\
\hline \multirow[t]{3}{*}{9} & Tracks & $1.34^{\mathrm{BC}}$ & 0.17 & 12.5 & $45.3^{\mathrm{BCDE}}$ & 6.8 & 15.0 & $13.6^{\mathrm{BCD}}$ & 5.5 & 40.3 \\
\hline & Between tracks & $1.16^{\mathrm{CD}}$ & 0.23 & 20.2 & $52.7^{\mathrm{AB}}$ & 9.5 & 18.1 & $17.3^{A B C}$ & 5.8 & 33.3 \\
\hline & Cutting strips & $1.17^{\mathrm{CD}}$ & 0.17 & 14.8 & $52.1^{\mathrm{ABC}}$ & 6.9 & 13.2 & $19.2^{\mathrm{AB}}$ & 4.8 & 24.8 \\
\hline \multirow[t]{3}{*}{15} & Tracks & $1.32^{\mathrm{BCD}}$ & 0.23 & 17.6 & $49.5^{\mathrm{ABC}}$ & 8.9 & 18.0 & $14.1^{\mathrm{BCD}}$ & 5.6 & 39.5 \\
\hline & Between tracks & $1.18^{\mathrm{CD}}$ & 0.15 & 12.9 & $53.7^{\mathrm{A}}$ & 6.0 & 11.1 & $19.1^{\mathrm{AB}}$ & 4.4 & 23.1 \\
\hline & Cutting strips & $1.19^{C D}$ & 0.17 & 9.3 & $53.7^{\mathrm{A}}$ & 4.3 & 8.0 & $22.5^{A}$ & 3.8 & 16.9 \\
\hline \multirow[t]{2}{*}{ Test } & F-value & 10.50 & - & - & 8.57 & - & - & 8.56 & - & - \\
\hline & $P$-value & $<0.001$ & - & - & $<0.001$ & - & - & $<0.001$ & - & - \\
\hline
\end{tabular}


Tab. 3 - Soil physical properties at a depth of 10-20 cm in different years after logging. (SD): standard deviation; (CV): coefficient of variation. Different letters after means indicate significant differences after Tukey's HSD test $(\alpha=0.05)$.

\begin{tabular}{|c|c|c|c|c|c|c|c|c|c|c|}
\hline \multirow{2}{*}{$\begin{array}{c}\text { Years after } \\
\text { logging }\end{array}$} & \multirow{2}{*}{ Sampling site } & \multicolumn{3}{|c|}{ Bulk density $\left(\mathrm{g} \mathrm{cm}^{-3}\right)$} & \multicolumn{3}{|c|}{ Total porosity (\%) } & \multicolumn{3}{|c|}{ Aeration porosity (\%) } \\
\hline & & Mean & SD & CV (\%) & Mean & SD & CV (\%) & Mean & SD & CV (\%) \\
\hline Untouched & Control & $1.28^{c}$ & 0.14 & 10.9 & $47.7^{\mathrm{ABC}}$ & 5.6 & 11.9 & $17.3^{\mathrm{A}}$ & 7.4 & 42.7 \\
\hline \multirow[t]{3}{*}{1} & Tracks & $1.48^{\mathrm{A}}$ & 0.19 & 12.9 & $44.2^{c}$ & 7.2 & 16.3 & $12.0^{\mathrm{D}}$ & 3.7 & 30.5 \\
\hline & Between tracks & $1.30^{\mathrm{BC}}$ & 0.2 & 15 & $47.8^{\mathrm{ABC}}$ & 7.9 & 16.5 & $13.2^{\mathrm{ABCD}}$ & 4.5 & 34.1 \\
\hline & Cutting strips & $1.32^{B C}$ & 0.15 & 11.5 & $48.4^{\mathrm{ABC}}$ & 6.3 & 12.9 & $14.7^{\mathrm{ABCD}}$ & 5.3 & 35.6 \\
\hline \multirow[t]{3}{*}{2} & Tracks & $1.50^{\mathrm{A}}$ & 0.2 & 13.3 & $43.5^{c}$ & 7.5 & 17.3 & $12.2^{\mathrm{BCD}}$ & 3.7 & 30.9 \\
\hline & Between tracks & $1.39^{\mathrm{ABC}}$ & 0.12 & 8.9 & $47.6^{\mathrm{ABC}}$ & 4.7 & 9.8 & $14.2^{\mathrm{ABCD}}$ & 4.7 & 32.9 \\
\hline & Cutting strips & $1.37^{\mathrm{ABC}}$ & 0.08 & 6 & $48.4^{\mathrm{ABC}}$ & 3.2 & 6.5 & $16.0^{\mathrm{ABCD}}$ & 5.3 & 33.1 \\
\hline \multirow[t]{3}{*}{6} & Tracks & $1.43^{\mathrm{AB}}$ & 0.25 & 17.7 & $46.0^{\mathrm{ABC}}$ & 9.5 & 20.7 & $12.3^{\mathrm{CD}}$ & 6.8 & 55 \\
\hline & Between tracks & $1.38^{\mathrm{ABC}}$ & 0.09 & 6.6 & $48.1^{\mathrm{ABC}}$ & 3.4 & 7.1 & $14.0^{\mathrm{ABCD}}$ & 3.5 & 25.4 \\
\hline & Cutting strips & $1.34^{\mathrm{ABC}}$ & 0.12 & 8.8 & $49.5^{\mathrm{ABC}}$ & 4.5 & 9 & $16.4^{\mathrm{ABCD}}$ & 5.5 & 33.6 \\
\hline \multirow[t]{3}{*}{9} & Tracks & $1.39^{\mathrm{ABC}}$ & 0.17 & 12.2 & $45.4^{\mathrm{BC}}$ & 6.7 & 14.7 & $13.2^{\mathrm{ABCD}}$ & 4.3 & 32.3 \\
\hline & Between tracks & $1.28^{\mathrm{BC}}$ & 0.14 & 11.1 & $49.7^{\mathrm{ABC}}$ & 5.6 & 11.3 & $16.9^{\mathrm{ABCD}}$ & 4.9 & 29 \\
\hline & Cutting strips & $1.28^{B C}$ & 0.12 & 9.3 & $49.6^{\mathrm{ABC}}$ & 4.7 & 9.5 & $18.1^{\mathrm{ABC}}$ & 7 & 38.9 \\
\hline \multirow[t]{3}{*}{15} & Tracks & $1.38^{\mathrm{ABC}}$ & 0.16 & 11.4 & $47.2^{\mathrm{ABC}}$ & 6 & 12.7 & $13.6^{\mathrm{ABCD}}$ & 5.8 & 42.2 \\
\hline & Between tracks & $1.26^{\mathrm{BC}}$ & 0.12 & 9.5 & $51.8^{\mathrm{AB}}$ & 4.6 & 8.9 & $17.3^{\mathrm{ABCD}}$ & 5.1 & 29.4 \\
\hline & Cutting strips & $1.25^{c}$ & 0.1 & 7.9 & $52.5^{\mathrm{A}}$ & 3.8 & 7.2 & $18.8^{A}$ & 6.8 & 36.4 \\
\hline \multirow[t]{2}{*}{ Test } & $F$-value & 6.51 & - & - & 3.55 & - & - & 4.61 & - & - \\
\hline & P-value & $<0.001$ & - & - & $<0.001$ & - & - & $<0.001$ & - & - \\
\hline
\end{tabular}

the control area. However, no statistical difference was detected $(p=0.10)$.

Where there was a direct impact from forest machinery, there were no significant differences between the control and experimental areas. However, in the first year after logging, there was an increase in soil bulk density (from $5.9 \%$ to $11.7 \%$ ), although not significant $(p>0.03)$.

The increase in soil bulk density of the tracks was reflected by a decrease in total porosity and soil aeration (at a depth of o$10 \mathrm{~cm})$. Similarly, a significant difference be tween the total porosity of the control area and that of the area between the tracks was found during the first nine years after logging. The total porosity of the tracks was reduced by $6.8-11.5 \%$. Fifteen years after logging, the total porosity values were also lower than those of un touched stands. However, there was no significant statistical difference $(p=0.09)$.

Over the first six years after logging, a significant difference between the aeration porosity of the control area and the area between the tracks was found. The aeration porosity was $6.1-7.3 \%$ lower. From 9 to 15 years after cutting, the aeration porosity was also $4.3-3.8 \%$ lower than in untouched areas, though this difference was not significant ( $p>0.06)$. With regards to aeration porosity, there was no significant difference between the control areas and areas where forest machinery had no direct impact $(p>0.05)$

At a soil depth of $10-20 \mathrm{~cm}$ (Tab. 3), a significant difference between the bulk density of the control area and that of the area between the tracks was found. Six years after logging, the bulk density in the tracks had increased by 11.7-17.2\%. However, the difference between the areas decreased over time. After 9-15 years since cutting, the soil had an $8.6-7.8 \%$ higher bulk density as compared with uncut stands, but there was no significant statistical difference $(p>$ $0.16)$.

Six years after logging, we found a significant difference between the total porosity of the control area and that of the tracks. The total porosity of the tracks was $1.7-4.2 \%$ lower than in control areas. Nine to fifteen years after logging, the total porosity was lower than in untouched stands. However, there was no significant statistical difference $(p>0.96)$.

Six years after logging, at a depth of 10-20 $\mathrm{cm}$, there was a significant difference in aeration between the control area and the area between the tracks. The aeration porosity in the tracks was $5.0-5.3 \%$ lower than in the control area. Nine to fifteen years years after felling, the aeration porosity was $4.1-3.7 \%$ lower than in untouched stands. However, there was no statistical difference $(p>0.06)$. There was also no significant difference between the aeration porosity of the control area and that of areas that had not been directly impacted by forest machinery $(p>0.07)$.

\section{Plant species recovery}

The Jaccard's index assessment of plant species similarity between sections of the grass-shrub layer from different years of felling showed that the highest indicator (61\%) was between the cutting strips in the first year of felling and the control area (Tab. 4). This indicates the maximum species similarity composition.

Over the next ten years, the floristic similarity of the cutting strips and control areas decreased to $50 \%$. Then, $13-15$ years after logging, the species similarity increased, rising to $52-57 \%$. The species composition within the track differs most from the control area. This pattern was consistent, with the area within the track being where the most logging residue and damage to plant cover was found.

After logging, there were strong changes in species composition of the plant cover (see Tab. S2 in Supplementary material). These changes were confirmed through the calculation of plant species similarity (Tab. 4). The total number of grass-shrub layer species varied greatly between areas, depending on the time since logging. The maximum amount of species were recorded in between the tracks, where the conditions were most heterogeneous.

Ten years after cutting, the projection cover of the grass-shrub and moss floors within and between the tracks approached that of the untouched cutting strips. In the first 5-7 years after cutting, the plant cover was affected by the growth of understory species. Over time, due to the significant growth of deciduous trees, the development of the moss layer slowed down. For example, in logging sites that were 4-6 years old, the lowest indicators of coverage were found in areas with high coverage of aspen and birch.

Analysis of bio-morphological groups did not show any fundamental differences between the sites, regardless of the differences in the time since logging. An exception to this was the ratio of shrub groups on the experimental units of the cutting area (the tracks, between tracks and cutting strips). A similar ratio to that of the control area was observed in sections 
where logging had occurred 13-15 years prior. Due to their morphological structure, shrubs were the least resistant to damage. The perennial aboveground was damaged by the logging equipment. Ecological-cenotic analysis showed that, at all sites, the cutting strips and areas between the tracks were dominated by forest-type plants. Within the tracks, the ratio of plant groups changed three years after logging. The percentage of species belonging to meadow and weed ruderal groups did not exceed $30 \%$. Due to conditions of high heterogeneity, both within and between tracks, the proportion of these plants increased a year after logging.

For the first few years after logging, the species composition of deep ruts fundamentally differed. For example, in the first 3-5 years after logging, the ruts that were filled with water were almost devoid of plants. Gradually, the sides of the rut became occupied by mosses (mainly Polytrichum commune), whilst the bottom became occupied by Sphagnum. Ruts that were filled with water for a long period became populated by species representatives of the wetland group (Hydrophytes-Typha latifolia and Equisetum fluviative). The following species of hygrophytes and helophytes grew in these ruts: Caltha palustris, Epilobium ciliatum, Eriophorum vaginatum, Equisetum palustre, Carex echinate and Carex vulpina. In dry, deep ruts, vegetative and mobile plants appeared. Within untouched forests, these species are often found in ecotones (e.g., forest edges, clearings, etc.). Almost all plants present belonged to either the long-rooted or the ground stem-forming bio-morphological groups. Fragaria vesca, Calamagrostis spp., Equisetum sylvaticum, Lathyrus pratensis, Ajuga reptans, Pulmonaria obscura and Rubus saxatilis were found in all sites. Trifolium repens, Tussilago farfara and Chamaenerion angustifolium were often present.

\section{Natural tree regeneration}

The untouched stand contained more than two-thousand of undergrowth individuals per hectare. The majority of this undergrowth consisted of shade-tolerant spruce (see Tab. S3 in the Supplementary material). In sparse areas, there was a mixture of deciduous trees (mainly birch and aspen).

After a year of logging, the undergrowth within and between tracks was completely destroyed. However, in cutting strips, most of the regeneration had been preserved and deciduous tree species and spruce were found. At this stage, the area was dominated by spruce.

Two years after cutting, some deciduous tree undergrowth appeared and, in some places, spruce was found within and between the tracks. Due to the renewal of deciduous trees, there was also an increase in the amount of undergrowth in the cutting strips. The ratio of the undergrowth composition changed in favour of decidu-

Tab. 4 - Plant species similarity index (\%) between logging and control sites over 15 years after logging operations.

\begin{tabular}{|c|c|c|c|c|c|c|c|c|c|c|c|}
\hline Where & $\begin{array}{c}\text { Years after } \\
\text { logging }\end{array}$ & 2 & 3 & 4 & 5 & 6 & 7 & 9 & 13 & 15 & Control \\
\hline \multirow{10}{*}{$\begin{array}{l}\stackrel{\widetilde{v}}{\mathrm{~J}} \\
\stackrel{\mathbb{V}}{=}\end{array}$} & 1 & 26 & 21 & 26 & 29 & 20 & 25 & 18 & 26 & 21 & 12 \\
\hline & 2 & - & 44 & 32 & 30 & 38 & 14 & 11 & 35 & 28 & 12 \\
\hline & 3 & - & - & 52 & 50 & 24 & 28 & 25 & 32 & 27 & 15 \\
\hline & 4 & - & - & - & 54 & 39 & 35 & 19 & 33 & 34 & 17 \\
\hline & 5 & - & - & - & - & 33 & 32 & 21 & 36 & 30 & 18 \\
\hline & 6 & - & - & - & - & - & 10 & 11 & 20 & 18 & 18 \\
\hline & 7 & - & - & - & - & - & - & 45 & 28 & 28 & 10 \\
\hline & 9 & - & - & - & - & - & - & - & 25 & 20 & 11 \\
\hline & 13 & - & - & - & - & - & - & - & - & 41 & 29 \\
\hline & 15 & - & - & - & - & - & - & - & - & - & 53 \\
\hline \multirow{10}{*}{ 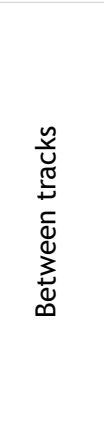 } & 1 & 24 & 33 & 28 & 36 & 28 & 24 & 20 & 28 & 33 & 26 \\
\hline & 2 & - & 53 & 50 & 37 & 37 & 16 & 17 & 15 & 25 & 19 \\
\hline & 3 & - & - & 29 & 40 & 29 & 24 & 18 & 29 & 35 & 33 \\
\hline & 4 & - & - & - & 38 & 31 & 25 & 18 & 21 & 29 & 20 \\
\hline & 5 & - & - & - & - & 37 & 26 & 19 & 25 & 42 & 33 \\
\hline & 6 & - & - & - & - & - & 14 & 18 & 21 & 21 & 15 \\
\hline & 7 & - & - & - & - & - & - & 50 & 19 & 31 & 18 \\
\hline & 9 & - & - & - & - & - & - & - & 21 & 16 & 15 \\
\hline & 13 & - & - & - & - & - & - & - & - & 56 & 42 \\
\hline & 15 & - & - & - & - & - & - & - & - & - & 54 \\
\hline \multirow{10}{*}{ 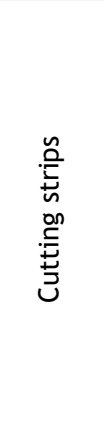 } & 1 & 50 & 44 & 24 & 42 & 40 & 21 & 25 & 30 & 40 & 61 \\
\hline & 2 & - & 46 & 26 & 55 & 58 & 21 & 26 & 29 & 35 & 33 \\
\hline & 3 & - & - & 31 & 47 & 40 & 25 & 32 & 42 & 54 & 51 \\
\hline & 4 & - & - & - & 38 & 26 & 20 & 31 & 27 & 23 & 13 \\
\hline & 5 & - & - & - & - & 51 & 16 & 26 & 28 & 38 & 37 \\
\hline & 6 & - & - & - & - & - & 15 & 24 & 26 & 26 & 34 \\
\hline & 7 & - & - & - & - & - & - & 35 & 30 & 28 & 23 \\
\hline & 9 & - & - & - & - & - & - & - & 35 & 41 & 27 \\
\hline & 13 & - & - & - & - & - & - & - & - & 38 & 52 \\
\hline & 15 & - & - & - & - & - & - & - & - & - & 57 \\
\hline
\end{tabular}

ous trees. This could be seen throughout the 15 -year period.

Six to seven years after logging, an increase in the amount of undergrowth was observed in all areas. The maximum abundance of undergrowth was found in cutting strips that had not been directly impacted by logging equipment. Within and between tracks, the amount of undergrowth was 2-7 times less than in cutting strips. This was due to deep ruts that contained unfavourable physical soil and a dense layer of felling residue, hampering the germination of woody species.

Fifteen years after logging, the amount of undergrowth had decreased in all areas, especially in the cutting strips which contained the maximum amount of undergrowth.

\section{Discussion}

\section{Rutting and logging residues}

The main type of soil damage due to logging operations was rutting. Our results on rut formation after logging are consistent with studies conducted by authors in the Karelia Republic of Russia (Gerasimov \& Katarov 2010). Numerous studies from different countries proved that the use of modern logging equipment in moist soil causes ruts often reaching 0.5 meters or more in depth (Katarov et al. 2012). However, the effects of skidding are highly sitespecific, depending on the actual site and weather conditions. Toivioa et al. (2017) shows that, when estimating the effects of harvesting operations, it is important to evaluate different factors and site characteristics.

Our results shows that rut depth can even reach $70 \mathrm{~cm}$ when harvesting is carried out in summer on temporarily moist soil and the cutting residue left on the ground is not enough (Tab. 1). The correlation between the amount of felling residue and rut depth showed an exponential trend. The more felling residue is present on the ground, the less likely deep soil damage are to occur.

Numerous studies showed that changes in soil properties (e.g., bulk density, poros- 
Fig. 4-Example A of overgrowth of deep ruts with a high-level groundwater occurrence and a weak flow (A) and a low-level groundwater occurrence (B).
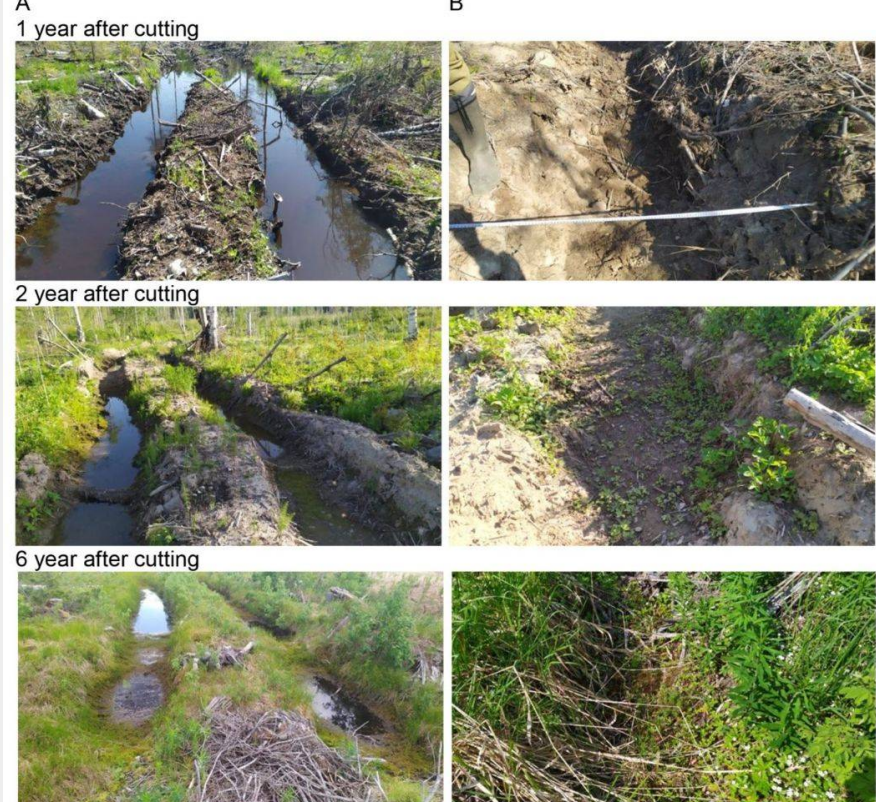

\section{9 year after cutting}

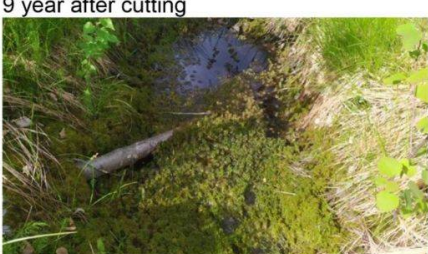

15 year after cutting
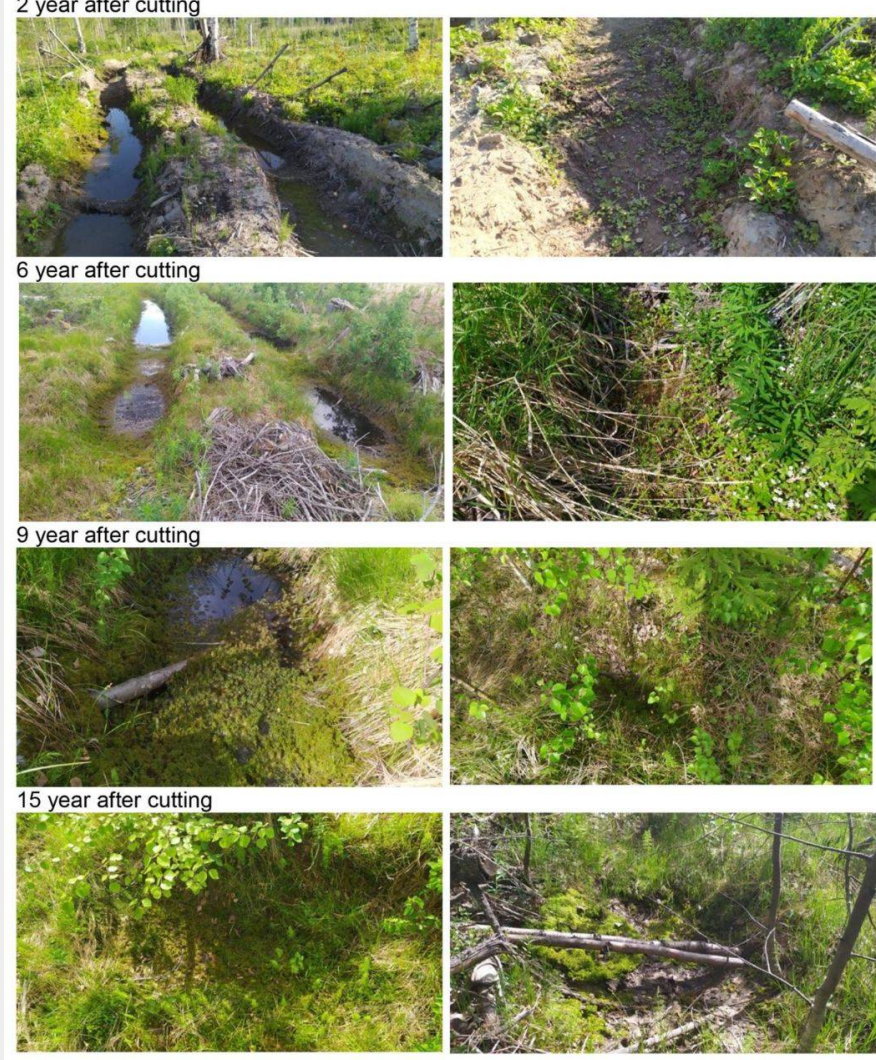

ity and rutting) are significantly reduced in skid trails reinforced with wood residue. Wood residue includes trunks of small-size trees, tops and branches (Eliasson \& Wästerlund 2007, Solgi et al. 2018). Felling residue also significantly increases the bearing capacity of the soil. When heavy equipment passes through reinforced skid trails, the weight of the machine is distributed over a larger area. Therefore, the pressure of the equipment per surface unit is much lower (Ampoorter et al. 2007). Labelle \& Jaeger (2012) reported a significant reduction in the peak load of soil when over $10 \mathrm{~kg}$ per $1 \mathrm{~m}^{2}$ of brushwood pad is used. It is recommended to leave at least $15-20 \mathrm{~kg} \mathrm{~m}^{-2}$ of brushwood on soil with a low bearing capacity (Labelle \& Jaeger 2012, 2019, Poltorak et al. 2018).

This study confirms that leaving $15-20 \mathrm{~kg}$ $\mathrm{m}^{-2}$ of felling residue can avoid creating deep ruts. In many cases, insufficient amounts of felling residue (up to $10 \mathrm{~kg} \mathrm{~m}^{-2}$ ) are used on skid trails, which covers the soil surface unevenly. In most cases, cutting strips contain an excess felling residue that can be laid over skid trails. Thus, the potential of felling residue to strengthen skid trails is often underutilised. However, the distribution of felling residue also de- pends on the original species composition, the stock of the stand and the distribution of the trees in the cutting area (Labelle \& Jaeger 2019). Moreover, due to the abandonment of key elements of the forest stand, non-operational areas and natural biotopes, the amount of available felling residue in local areas has decreased. Therefore, careful planning of the skid trail network and meaningful strengthening of skid trails (using cutting residue) is required. Furthermore, the distribution of cutting residue along the skid trails is also important. Indeed, the maximum amount of felling residue should be left at the beginning of the skid trail, which is traveled more times by forwarders moving back and forth to the loading area.

\section{Changes in physical soil properties}

The main effect of logging operations on soil is soil compaction, which is directly measured by soil bulk density. It is believed that the greatest increase in soil compaction occurs at a depth of $10 \mathrm{~cm}$. At 20 $\mathrm{cm}$, this lessens and the same happens at $30 \mathrm{~cm}$ (Akay et al. 2007).

Similar results were obtained in this study. Skidding led to compaction in the tracks, whereas significant soil compaction did not occur in between the tracks and in cutting strips. In this case, the maximum soil bulk density was achieved in the initial years after cutting. In the following years, soil compaction decreased and, after 15 years, the soil compaction had almost reached that of the cutting strips not traveled by the logging equipment.

On fresh cutting areas, soil compaction at a depth of $0-10 \mathrm{~cm}$ was consistently observed, increasing the track bulk density by 14-27\% (min: 16-24\%, max: 7-38\%). At a depth of $10-20 \mathrm{~cm}$, soil compaction was less noticeable, as the bulk density in the tracks increased by only $7-17 \%$. Soil compaction was not found in the areas between tracks or in cutting strips, though in some areas the bulk density was higher than in the control area.

Changes in soil density and associated air, heat, and water regimes affect soil organisms and plants. They also have a negative impact on forest productivity (Kozlowski 1999, McNabb et al. 2001, Ares et al. 2005, Cambi et al. 2015). It is proven that increasing bulk density reduces pores and available moisture, affecting the root systems of plants (Susnjar et al. 2006), thus leading to a reduction in available nutrients and poor plant growth.

In both fresh and old cutting areas, at a depth of $0-20 \mathrm{~cm}$, the aeration porosity was lower than $10 \%$. These areas had the growing conditions typical of spruce forests (such as myrtillosum-wet and polytrichosa forests), including temporarily excessive moisture. Nonetheless, the study areas provided satisfactory conditions for the growth and development of woody vegetation, as evidenced by the abundance of undergrowth and various tree species. This holds for the areas within and between the tracks as well. However, the subsequent restoration of natural vegetation can be locally hindered within the skid trails due to compaction of the upper soil horizons and deep ruts.

\section{Changes in the species composition of plant cover}

Understory vegetation often undergo significant changes during and after clear-cutting (Okland et al. 2003, Zenner et al. 2006). The nature of these changes depends on the method of cutting, harvesting systems and season of wood harvesting. Canopy thinning leads to the growth of herbaceous vegetation, as well as the colonization by random species (Roberts \& Zhu 2002). Various authors noted that weed phytocoenoses are very dynamic in clear-cuttings (Genikova \& Kryshen 2018). Plant communities can exhibit strong inertia and it can take many years for the consequences of logging to become less noticeable (Johnson et al. 2014). The changes in microenvironmental conditions in the post-harvest habitat create new ecological niches, leading to changes in plant cover and composition, and different ecologicalcenotic groups to establish. Ilintsev et al. 
(2019b) showed that the growth and species diversity of the vegetation are different in different parts of the cutting area (cutting strip, skid trail and loading points), depending on local disturbance and the time since cutting. Maximum heterogeneity is typical of severe soil damages and forest loading sites.

In the study area, the subsequent restoration of vegetation cover in deep ruts occurs in different ways, depending on the long-term stagnant water conditions (Fig. 4). First, a moss-dominated cover can develop starting in the cavaliers and then on the rut walls. After the gradual reduction of excess water, moss covers the bottom of the rut. Fifteen years after cutting, some ruts were completely covered by mosses, whilst others had an open water mirror, which can delay the establishment of vegetation for several decades. Alternatively, a grass and shrub-dominated cover may occur simultaneously on the cavaliers and the rut side walls, as well as at the bottom of the rut where no long-term water stagnation occurs. In this case, over a 15-year period the ruts were almost completely covered by plants. In both cases, the presence of stagnant water in the ruts is depending on the forest growing conditions (polytrichosa and myrtillosum-wet), as well as the amount of precipitation in the spring.

\section{Natural tree regeneration in clear- cuttings}

During a long period of intense exploitation of forests in Northern Russia, pine was replaced by spruce and birch. Spruce was then replaced by birch and aspen. This phenomenon takes place in $50-70 \%$ of clear-cuttings in the Taiga zone (Melehov 2003).

Our research confirmed that the renewal of deciduous species, primarily birch and aspen, dominated in the observed areas, though spruce regeneration is sufficient in some areas. This implies the formation of mixed deciduous and coniferous stands in the long run. The results of natural regeneration studies showed that the amount of undergrowth of tree species is dependent on the age of cutting. Within and between tracks, the amount of undergrowth for all tree species is several times less than in cutting strips. Therefore, soil properties, the amount of felling residue, and rut depth, all have an impact on rut areas recover, especially in the first years after logging.

\section{Conclusions}

Based on our results the following conclusions can be drawn:

1. Studying cutting areas over 15 years after logging has shown that changes to the physical properties of the upper soil horizons are temporary and localised. The prominence of the ruts and the likelihood of water stagnation and/or excess moisture on skid trails decrease over time.

2. We found no increase in the depth and width of ruts over the period considered. In most cases, the ruts served as collectors of excess water in wetter seasons and during periods of increased precipitation.

3. During the 15-year period after logging, the plant cover in the skid trails was restored, except in excessively wet deep ruts. The soil surface remained covered with a dense layer of felling residue. The growth of grass-shrub and moss layers in skid trails was intensive and contributed to the consolidation of existing wheel tracks, thus preventing the erosion process.

4. The complex soil and environmental conditions in cutting areas are satisfactory for the renewal of tree and shrub species. This in turn will increase moisture drainage and reduce the excessive moisture stagnation in the ruts.

5. As a consequence of climate change, excessive moisture in the soil may occur with increasing frequency in the future. Monitoring seasonal phenomena at the beginning and end of the spring and autumn is necessary to correct logging activities on soil with temporarily excessive moisture.

6. Logging practices should be improved to limit their negative environmental impact. The most important best management practice would be more careful planning of the skid trail network and the strengthening of skid trails using felling residue. The distribution of 15-20 $\mathrm{kg} \mathrm{m}^{-2}$ felling residue over skid trails can prevent the formation of deep ruts.

\section{Acknowledgments}

This study was funded by the Russian Foundation for Basic Research (RFBR), according to Research Projects no. 18-3400315 and no. 17-44-290127. It was carried out as part of a state assignment of the Northern Research Institute of Forestry (no. AAAA-A19-119012590188-3). We are grateful to anonymous reviewers for their insightful and helpful comments.

\section{References}

Akay AE, Yuksel A, Reis M, Tutus A (2007). The impacts of ground-based logging equipment on forest soil. Polish Journal of Environmental Studies 16 (3): 371-376. [online] URL: http:// www.researchgate.net/publication/285866113

Ampoorter E, Goris R, Cornelis WM, Verheyen K (2007). Impact of mechanized logging on compaction status of sandy forest soils. Forest Ecology and Management 241 (1-3): 162-174. - doi: 10.1016/j.foreco.2007.01.019

Anonymous (2018). The forest plan of the Arkhangelsk Region. Arkhangelsk, Russia, pp. 298. [in Russian] [online] URL: https://portal. dvinaland.ru/upload/iblock/ecf/LesPlan_Ukaz_1 16-\%D1\%83_ot_\%2014_12_2018.pdf

Ares A, Terry T, Miller R, Anderson H, Flaming B (2005). Ground-based forest harvesting effects on soil physical properties and Douglas-fir growth. Soil Science Society of America Journal 69: 1822-1832. - doi: 10.2136/sssaj2004.0331
Cambi M, Certini G, Neri F, Marchi E (2015). Impact of heavy traffic on forest soils: a review. Forest Ecology and Management 338: 124-138. doi: 10.1016/j.foreco.2014.11.022

Dymov AA (2017). The impact of clearcutting in boreal forests of Russia on soils: a review. Eurasian Soil Science 50 (7): 780-790. - doi: 10.113 4/S106422931707002X

Eliasson L (2005). Effects of forwarder tyre pressure on rut formation and soil compaction. Silva Fennica 39 (4): 549-557. - doi: 10.14214/sf. 366

Eliasson L, Wästerlund I (2007). Effects of slash reinforcement of strip roads on rutting and soil compaction on a moist fine-grained soil. Forest Ecology and Management 252(1-3): 118-123. doi: 10.1016/j.foreco.2007.06.037

Genikova NV, Kryshen AM (2018). Dinamika napochvennogo pokrova severotaezhnogo el'nika chernichnogo $v$ pervye gody posle rubki [Dynamics of ground cover in Piceetum myrtillosum in northern taiga during the first years after clear-cutting]. Botanicheskii Zhurnal 103 (3): 364-381. [in Russian with English summary] doi: 10.1134/S0006813618030067

Gerasimov Y, Katarov V (2010). Effect of bogie track and slash reinforcement on sinkage and soil compaction in soft terrains. Croatian Journal of Forest Engineering 31 (1): 35-45. [online] URL: http://hrcak.srce.hr/56926

Goltsev V, Tolonen T, Syunev V, Dahlin B, Gerasimov $Y$ (2011). Wood harvesting and logistics in Russia - Focus on research and business opportunities. METLA Working Papers no. 210, Forest Research Institute, Vantaa, Finland, pp. 157. [online] URL: http://www.metla.fi/julkaisut/wor kingpapers/2011/mwp210.htm

Gustafson EJ (1996). Expanding the scale of forest management: allocating timber harvests in time and space. Forest Ecology and Management 87: 27-39. - doi: 10.1016/S0378-1127(96)038 38-8

Hartmann M, Niklaus PA, Zimmermann $S$, Schmutz S, Kremer J, Abarenkov K, Lüscher P, Widmer F, Frey B (2014). Resistance and resilience of the forest soil microbiome to logging-associated compaction. Multidisciplinary Journal of Microbial Ecology 8 (1): 226-244. doi: 10.1038/ismej.2013.141

llintsev A, Nakvasina E, Aleynikov A, Tretyakov S, Koptev S, Bogdanov A (2018). Middle-term changes in topsoils properties on skidding trails and cutting strips after long-gradual cutting: a case study in the boreal forest of the NorthEast of Russia. Croatian Journal of Forest Engineering 39 (1): 71-83. [online] URL: http://www. crojfe.com/site/assets/files/4189/ilintsev.pdf Ilintsev A, Tretyakov S, Amosova I (2019a). Ekologo-biologicheskij analiz vliyaniya razlichny vidov rubok na strukturu travyano-kustarnichkovogo yarusa chernichnyh tipov lesa [The effect of different cuttings on the ecological-biological structure of the grass-shrub layer in the blueberry forest]. Forestry Engineering Journal 9 (1): 31-44. [in Russian with English Abstract] doi: 10.12737/article_5c92016c7c7264.61401393 Ilintsev AS, Bogdanov AP, Bykov Y (2019b). Dinamika fizicheskih svojstv podzolistoj pochvy na vyrubkah pri estestvennom zarastanii [Physical properties dynamics of podzolic soil in the naturally regenerated cutover areas]. Lesnoy 
Zhurnal 5: 70-82. [in Russian with English summary] - doi: 10.17238/issno536-1036.2019.5

IPCC (2013). Climate change 2013: the physical science basis. Contribution of Working Group I to the Fifth Assessment Report of the Intergovernmental Panel on Climate Change (Stocker $\mathrm{TF}$, Qin D, Plattner G-K, Tignor M, Allen SK, Boschung J, Nauels A, Xia Y, Bex V and Midgley PM eds). Cambridge University Press, Cambridge, United Kingdom and New York, NY, USA, pp. 1535. [online] URL: http://www. climatechange2013.org/images/report/WG1AR5 ALL_FINAL.pdf

IUSS Working Group WRB (2015). World reference base for soil resources. International soil classification system for naming soils and creating legends for soil maps. World Soil Resources Reports no. 106, FAO, Rome, Italy, pp. 181.

Johnson S, Strengbom J, Kouki J (2014). Low levers of tree retention do not mitigate the effects of clearcutting on ground vegetation dynamics. Forest Ecology and Management 330: 67-74. - doi: 10.1016/j.foreco.2014.06.031

Katarov V, Syunev V, Ratkova E, Gerasimov Y (2012). Vliyanie forvarderov na lesnye pochvogrunty [Impact of wood forwarding on forest soils]. Trudy Lesoinzhenernogo Fakul'teta PETRGU 9: 73-81. [in Russian with English summary]

Klaes B, Struck J, Schneider R, Schüler G (2016). Middle-term effects after timber harvesting with heavy machinery on a fine-textured forest soil. European Journal of Forest Research 135: 1083-1095. - doi: 10.1007/s10342-016-0995-2

Kozlowski TT (1999). Soil compaction and growth of woody plants. Scandinavian Journal of Forest Research 14 (6): 596-619. - doi: 10.1080/02827589908540825

Krebs CJ (1999). Ecological methodology ( $2^{\text {nd }}$ edn). Addison-Wesley Longman, Menlo Park, CA, USA, pp. 620.

Kurnaev SF (1973). Lesorastitel'noe rajonirovanie SSSR [Forest growth zoning of the USSR]. Science, Moscow, Russia, pp. 203. [in Russian]

Labelle ER, Jaeger D (2012). Quantifying the use of brush mats in reducing forwarder peak loads and surface contact pressure. Croatian Journal of Forest Engineering 33 (2): 249-274. [online] URL: http://hrcak.srce.hr/116844

Labelle ER, Jaeger D (2019). Management implications of using brush mats for soil protection on machine operating trails during mechanized cut-to-length forest operations. Forests 10 (19): 1-30. - doi: 10.3390/f10010019

Marchi E, Chung W, Visser R, Abbas D, Nordfjell T, Mederski PS, McEwan A, Brinkh M, Laschi A (2018). Sustainable forest operations (SFO): a new paradigm in a changing world and climate. Science of the Total Environment 634: 13851397. - doi: 10.1016/j.scitotenv.2018.04.084

Marchi E, Picchio R, Mederski PS, Vusić D, Perugini $M$, Venanzi $R$ (2016). Impact of silvicultural treatment and forest operation on soil and regeneration in Mediterranean Turkey oak (Quercus cerris L.) coppice with standards. Ecological Engineering 95: 475-484. - doi: 10.1016/j.ecolen g.2016.06.084

McNabb D, Startsev A, Nguyen H (2001). Soil wetness and traffic level effects on bulk density and air-filled porosity of compacted boreal forest soils. Soil Science Society of America Journal 65: 1238-1247. - doi: 10.2136/sssaj2001.654123 $8 \mathrm{x}$

Melehov IS (2003). Lesovodstvo: uchebnik dlja vuzov [Silviculture: textbook for universities]. MSFU Publ., Moscow, Russia, pp. 302. [in Russian]

Modry M, Hubeny D (2003). Impact of skidder and high-lead system logging on forest soils and advanced regeneration. Journal of Forest Science 49 (6): 273-280. - doi: 10.17221/4701-JFS Mohieddinnea H, Brasseura B, Spichera F, GalletMorona E, Buridanta J, Kobaissib A, Horena $\mathrm{H}$ (2019). Physical recovery of forest soil after compaction by heavy machines, revealed by penetration resistance over multiple decades. Forest Ecology and Management 449: 1-10. doi: 10.1016/j.foreco.2019.117472

Nitsenko AA (1969a). K istorii formirovaniya sovremennyh tipov melkolistvennyh lesov severozapada evropejskoj chasti SSSR [On the history of the formation of modern types of smallleaved forests in the North-West of the European part of the USSR]. Botanicheskii Zhurnal 54 (1): 3-13. [in Russian with English summary]

Nitsenko AA (1969b). Ob izuchenii ekologicheskoj struktury rastitel'nogo pokrova [On the study of the ecological structure of vegetation cover]. Botanicheskii Zhurnal 54 (7): 1002-1013. [in Russian with English summary]

Okland T, Rydgren K, Okland RH, Storaunet KO, Rolstad J (2003). Variation in environmental conditions, understorey species number, abundance and composition among natural and managed Picea abies forest stands. Forest Ecology and Management 177: 17-37. - doi: 10.1016/ S0378-1127(02)00331-6

Osman KT (2013). Forest soils: properties and management. Springer International Publishing, Cham, Switzerland, pp. 217. - doi: 10.1007/ 978-3-319-02541-4_2

Pall R, Mohsenin NN (1980). A soil air pycnometer for determination of porosity and particle density. Transactions of the American Society of Agricultural Engineers 23 (3): 735-741. - doi: 10.13031/2013.34655

Plantarium (2020). Open on-line atlas and key to plants and lichens of Russia and neighbouring countries. Web site. [in Russian] [online] URL: http://www.plantarium.ru

Pobedinskii AV (2013). Vodoohrannaja i pochvozashhitnaja rol' lesov: vtoroe izdanie [Water and soil protection role of forests: $2^{\text {nd }}$ edition]. ALLRussian Research Institute for Silviculture and Mechanization of Forestry, Pushkino, Russia, pp. 208. [in Russian]

Poltorak BJ, Labelle ER, Jaeger D (2018). Soil displacement during ground-based mechanized forest operations using mixed-wood brush mats. Soil and Tillage Research 179: 96-104. doi: 10.1016/j.still.2018.02.005

Roberts MR, Zhu LX (2002). Early response of the herbaceous layer to harvesting in a mixed coniferous-deciduous forest in New Brunswick, Canada. Forest Ecology and Management 155 (1-3): 17-31. - doi: 10.1016/S0378-1127(01)00544-8 Sirén $M$, Ala-llomäki J, Lindeman $\mathrm{H}$, Uusitalo J, Kiilo KEK, Salmivaara A, Ryynänen A (2019). Soil disturbance by cut-to-length machinery on midgrained soils. Silva Fennica 53 (2): 1-24. - doi: 10.14214/sf.10134

Smirnova OV, Bobrovsky MV, Khanina LG (2017). European Russian forests. Their current state and features of their history. Springer Science+Business Media B.V., Dordrecht, Netherlands, pp. 566. - doi: 10.1007/978-94-024-1172-0 Soil Data Center (2011). Soil atlas of the Russian federation. MV Lomonosov Moscow State University, Moscow, Russia, pp. 632. [in Russian] [online] URL: http://soilatlas.ru/

Solgi A, Naghdi R, Labelle ER, Zenner EK (2018). The effects of using soil protective mats of varying compositions and amounts on the intensity of soil disturbances caused by machine traffic. International Journal of Forest Engineering 29 (3): 1-9. - doi: 10.1080/14942119.2018.152 7174

Susnjar M, Horvat D, Seselj J (2006). Soil compaction in timber skidding in winter conditions. Croatian Journal of Forest Engineering 27 (1): 315. [online] URL: http://www.crojfe.com/site/ assets/files/3919/susnjar.pdf

Terinov NN, Gerts EF, Bezgina YN (2016). Razvitie tekhniki i tekhnologij lesozagotovok na Urale [Development of logging technology in the Urals]. Lesnoy Zhurnal 2: 81-90. [in Russian with English summary] - doi: 10.17238/issno536-103 6.2016.2.81

Toivioa J, Helmisaaria H-S, Palviainena $M$, Lindemanb H, Ala-llomäkic J, Sirénc M, Uusitalob J (2017). Impacts of timber forwarding on physical properties of forest soils in southern Finland. Forest Ecology and Management 405: 2230. - doi: 10.1016/j.foreco.2017.09.022

WFO (2020). World flora online. World Flora Online Consortium, Web site. [online] URL: http:// www.worldfloraonline.org

Zenner EK, Kabrick JM, Jensen RG, Peck JE, Grabner JK (2006). Responses of ground flora to a gradient of harvest intensity in the Missouri Ozarks. Forest Ecology and Management 222: 326-334. - doi: 10.1016/j.foreco.2005.10.027

\section{Supplementary material}

Tab. S1 - Brief description of the study areas.

Tab. S2 - Changes in the composition of plant cover in different years after logging.

Tab. S3 - Statistical parameters of the undergrowth in different years after logging.

Link: Ilintsev_3371@supplo01.pdf 